\title{
C anadian Prairie growing season precipitation variability and associated atmospheric circulation
}

\author{
B. R. Bonsal*, X. Zhang, W. D. Hogg \\ Climate Research Branch, Atmospheric Environment Service, Downsview, Ontario M 3H 5T4, Canada
}

\begin{abstract}
Canadian Prairie growing season (M ay to August) precipitation variability and associated atmospheric circulation patterns are examined for the period 1905 to 1996 . The majority of precipitation and atmospheric variables generally displayed substantial interannual, as well as interdecadal, variability. The analysis identifies 5 decadal scale periods when the temporal distribution of precipitation (as measured by changes in the weighted centre of $30 \mathrm{~d}$ moving window precipitation totals) significantly shifted to earlier or later in the growing season. M onthly precipitation variability accounted for the observed shifts in temporal distribution including significantly low J uly-August rainfall from the mid 1910s to the mid 1940s, and a significant increase in May precipitation in the early 1970s. In addition, since 1980, J uly has replaced J une as the month of maximum precipitation. Mid-tropospheric and sea-level pressure atmospheric indices are developed to examine the synoptic scale flow characteristics associated with precipitation variability. Indices at the $500 \mathrm{hPa}$ and, to a lesser extent, surface levels explain a substantial portion of variance in monthly precipitation, and are also generally related to shifts in the temporal distribution. Since 1974, May $500 \mathrm{hPa}$ circulation has been characterized by a lower frequency of ridging (troughing) over western (eastern) Canada resulting in significantly higher May precipitation over the Prairies. The interdecadal variability in J uly and August precipitation was influenced by decadal variations in surface circulation involving the continental low over the southcentral United States, the high pressure over Arctic Canada, and the low pressure over eastern Canada. In particular, a substantial lowering of surface pressure over the continental United States from approximately the mid 1970s to the present appears to have contributed to the recent increase in later growing season precipitation over the Prairies.
\end{abstract}

KEY WORDS: Canadian Prairies - Growing season - Precipitation variability - Temporal distribution · $500 \mathrm{hPa}$ circulation $\cdot$ Sea level pressure

\section{INTRODUCTION}

The Canadian Prairies, situated in the west-central region of Canada (see Fig. 1), are highly dependent on precipitation especially during the growing season of May to August when the majority (up to two-thirds) of annual precipitation is received (Longley 1972, Dey 1982). Average growing season values range from over $300 \mathrm{~mm}$ in west-central Alberta and eastern Manitoba, to less than $200 \mathrm{~mm}$ in southern Alberta and into southwestern Saskatchewan (Fig. 2). This precipitation is critical to several environmental processes and economic activities and, most notably, to agriculture. There is normally just enough precipitation to sustain agriculture, particularly in the semi-arid regions of

*E-mail: barrie.bonsal@ec.gc.ca southwestern Saskatchewan and southern Alberta. As a result, regional scale precipitation deficits often have severe effects. For example, during 1961 (the worst single-year drought on the Prairies, with approximately $50 \%$ of normal growing season precipitation), total net farm income dropped by $48 \%$ ( $\$ 300$ million) from the previous year (Canadian National Committee for the International Decade for Natural Disaster Reduction 1994).

A nother important factor is the temporal distribution of precipitation within the growing season. Over the agricultural region of the Prairies, maximum rainfall normally occurs from mid J une to early J uly. The timing is advantageous since this is also the period of highest water demand for the growth of crops (Chakravarti 1972). Variations in this temporal distribution can also have severe effects. In 1988, May and June 


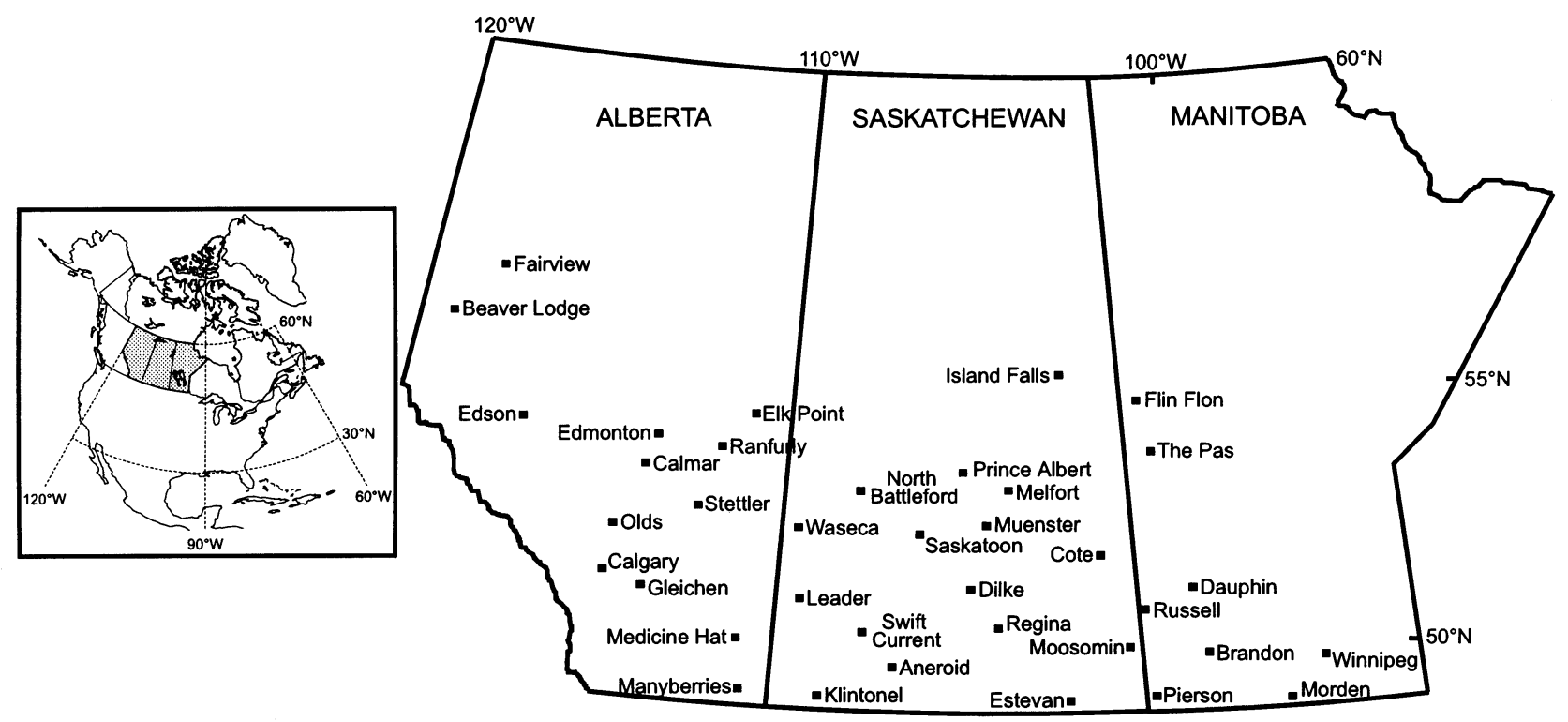

Fig. 1. Canadian Prairie study area and precipitation stations. The shaded region in the box to the left displays the geographical location of the Canadian Prairies with respect to N orth A merica

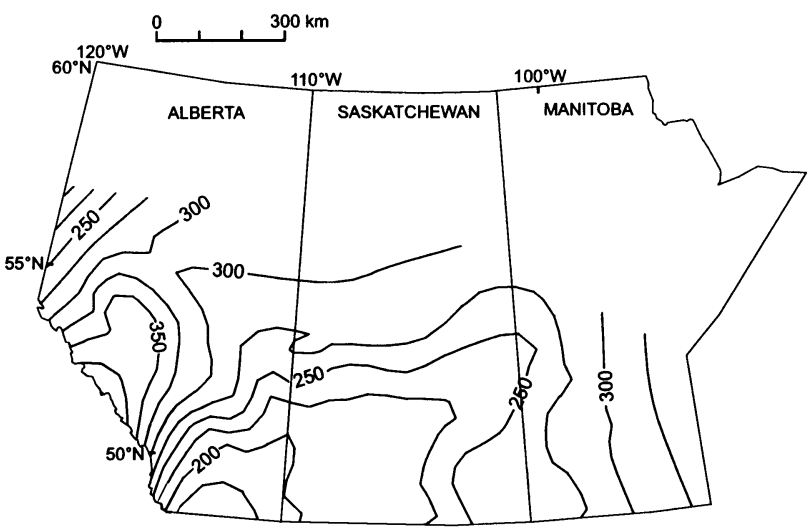

Fig. 2. Average growing season (M ay to August) precipitation on the Canadian Prairies (1961-90). Contour interval is $25 \mathrm{~mm}$. Stations used for the contouring procedure are shown in Fig. 1

precipitation was well below normal, while late J uly and August had ample rainfall, resulting in near normal total growing season precipitation. However, the very dry conditions during the most critical period for crop growth contributed to one of the worst crop yields this century (Wheaton et al. 1992). The growing season of 1954 had the second highest precipitation on record, yet crop production was approximately $30 \%$ below normal (Canadian National Committee for the International Decade for Natural Disaster Reduction 1994). The low yields were likely attributable to anomalously high rainfall during both the very early and late portions of the growing season, thereby causing delays in the planting, maturation, and harvesting of crops.

Variations in growing season precipitation are mainly determined by the storm track position and associated cyclonic and frontal activity. Convective precipitation due to surface heating can also be a major contributor during the warmer summer months (Longley 1972). Mid-tropospheric circulation is characterized by a large scale ridge whose mean position is west of the Canadian Prairies during the growing season. This results in a general northwesterly flow and associated advection of negative vorticity and subsidence over the Prairie region (Harman \& Braud 1975). Prolonged dry periods and droughts are normally caused by an unusually persistent, stronger than normal ridge which blocks the flow and displaces cyclonic tracks to the north of the study area. At higher levels, the jet stream is positioned in a northwest-southeast direction over the northern Prairies (Dey 1982). Dry spring and summer months have also been associated with the positive phase of the Pacific N orth American (PNA) pattern at the $500 \mathrm{hPa}$ level (Knox \& Lawford 1990). At the surface, dry periods are generally related to a higher frequency of migratory warm anticyclones over the Prairie region (Dey \& Chakravarti 1976). Low rainfall amounts have also been linked to persistent, strong surface westerlies over central North America including the Canadian Prairies (Borchert 1950). A nomalously wet conditions are associated with a collapse of the mid-tropospheric ridge and thus a higher 
frequency of zonal flow over the study area. The upper level jet stream is often displaced southward in a westeast alignment along the Canada-United States border causing surface level cyclones to be steered over the Prairies (Dey 1977). The wet conditions are aided by the advection of moist air into the Prairies from the southern United States and the Gulf of M exico.

Recently, there have been several investigations into the variability, trends, and changes of meteorological variables over various regions of the world. Precipitation results have generally indicated considerable spatial and temporal variations during the past century. Over the United States, for example, Karl et al. (1995) determined that area-averaged total precipitation has varied considerably both regionally and across the entire country on decadal scales. No definite centuryscale precipitation trends were discernible; however, since around 1970, amounts have tended to remain approximately 5\% above the mean for the entire 20th century. The increases were mainly attributable to higher precipitation during the autumn season. Substantial interdecadal variability has also been observed for Canadian precipitation (Groisman \& Easterling 1994). Within this variability, annual precipitation south of $55^{\circ} \mathrm{N}$ has increased by approximately $13 \%$ since the beginning of the century, and by $17 \%$ over northern Canada in the last $40 \mathrm{yr}$. Specifically for the Canadian Prairies, Bootsma (1994) found no significant trends in summer (J une-August) precipitation for selected stations from the late 1880 s to the present.

The above demonstrates the importance of growing season precipitation to the Canadian Prairies. Any significant changes or variations in the amount and/or temporal distribution within the growing season can have severe effects. To date, no studies have specifically focused on growing season precipitation variability over this region and, in particular, the important aspect of variations in the temporal distribution. The main purpose of this investigation is to identify and understand the causes of growing season precipitation variability on the Prairies for the period 1905-96. This includes examination of the associated mid-tropospheric and sea-level pressure (SLP) circulation patterns. The data sources are provided in Section 2, while Sections 3 and 4 examine the temporal distribution and amount of growing season precipitation respectively. Results of the atmospheric analyses are presented in Section 5 which is followed by a discussion with concluding remarks.

\section{STUDY AREA AND DATA}

The study area for the precipitation analysis approximates the agricultural growing region of the Canadian
Prairies which includes the southern portions of Alberta, Saskatchewan, and Manitoba (Fig. 1). The precipitation data consist of growing season (May to August) daily values for the 37 stations shown in Fig. 1. They are obtained from a Canadian precipitation data set (originating from the Atmospheric Environment Service archives) in which daily amounts have been adjusted to account for site and instrument changes, wind undercatch, evaporation, wetting loss, and trace events (M ekis \& Hogg 1999). The stations in Fig. 1 are chosen on the basis of record length, relatively few missing data, and good spatial coverage of the study area. Since this investigation focuses on regional scale precipitation variability over the Prairies, the majority of the analyses incorporate areally averaged (i.e. average for the 37 stations) precipitation variables. If a station's data are missing for a particular period (e.g. month), it is not used in the areally averaging procedure for that period. This does not have an appreciable effect after 1930 since the highest number of missing stations for any particular month is only 4 . However, due to varying record lengths, the number of stations are constantly reduced from 35 in 1930 to 15 in 1905. These fewer stations are generally evenly distributed across the study area. In addition, a statistical comparison of areal averages from these 15 stations with those from all 37 stations for the period 1930-96 reveals no significant differences in any of the derived precipitation variables. Nonetheless, some caution is required in the interpretation of the earlier results.

M id-tropospheric circulation data from 1946-96 consist of monthly (12:00 h UTC) $500 \mathrm{hPa}$ height analyses of the Northern Hemisphere $\left(15^{\circ}\right.$ to $\left.90^{\circ} \mathrm{N}\right)$ on a 455 point, $5^{\circ}$ latitude by $10^{\circ}$ longitude grid as outlined by Shabbar et al. (1990). M onthly $500 \mathrm{hPa}$ height anomalies are calculated relative to the $51 \mathrm{yr}$ base period. The surface circulation data is taken from the United Kingdom Meteorological Office (UKMO) gridded mean SLP series for the period 1905-93. They consist of daily values (on a $5^{\circ}$ latitude by $10^{\circ}$ longitude diamond grid) over the Northern Hemisphere $\left(15^{\circ}\right.$ to $90^{\circ} \mathrm{N}$ ). Data for certain regions are missing, particularly before 1930 and during the war years of the early 1940s. However, the majority of these missing values occur over the oceans and thus should not significantly affect this investigation, which focuses on circulation patterns near the Prairies. Further details regarding these data are provided in J ones (1987). Daily values are used to generate monthly averages. M onthly SLP anomalies are calculated relative to the $1905-93$ base period.

The statistical significance of differences between the means of 2 populations is assessed using the standard 2-tailed Student's t-test (e.g. Norman \& Streiner 1986) and the non-parametric Wilcoxon rank-sum test 
(Bethea et al. 1995). The second test, based on ranked data, is not influenced by extremely large or small precipitation amounts. A result is reported as statistically significant if both tests show a difference between the means at the $5 \%$ level.

\section{TEM PORAL DISTRIBUTION OF GROWING SEASON PRECIPITATION}

Variability in the temporal distribution of precipitation is analyzed using $30 \mathrm{~d}$ moving window precipitation totals within the growing season (i.e. May 1 to 30,

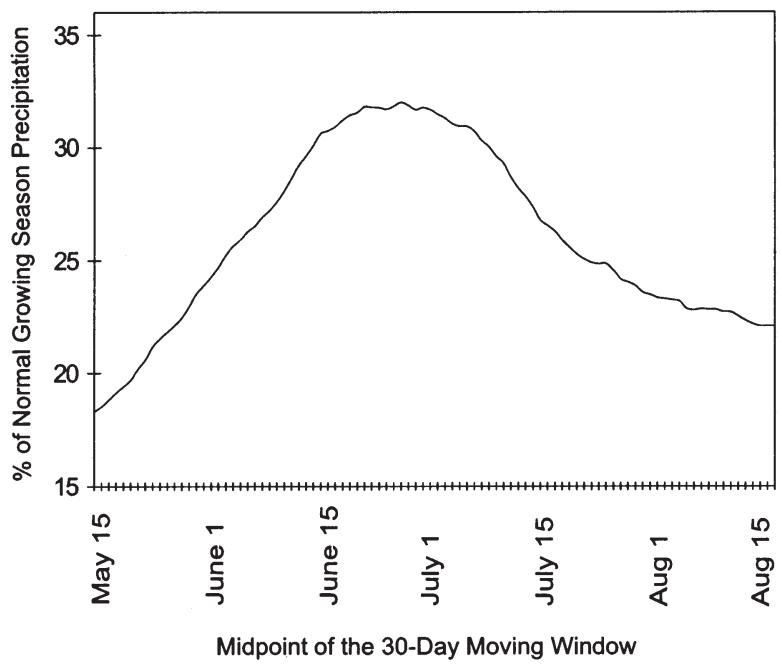

Fig. 3. A really averaged temporal distribution of $30 \mathrm{~d}$ moving window growing season precipitation on the Canadian Prairies for 1905-96. Each $30 \mathrm{~d}$ precipitation amount is expressed as a percentage of average total growing season precipitation for 1905-96. Dates refer to the midpoint of the $30 \mathrm{~d}$ moving window

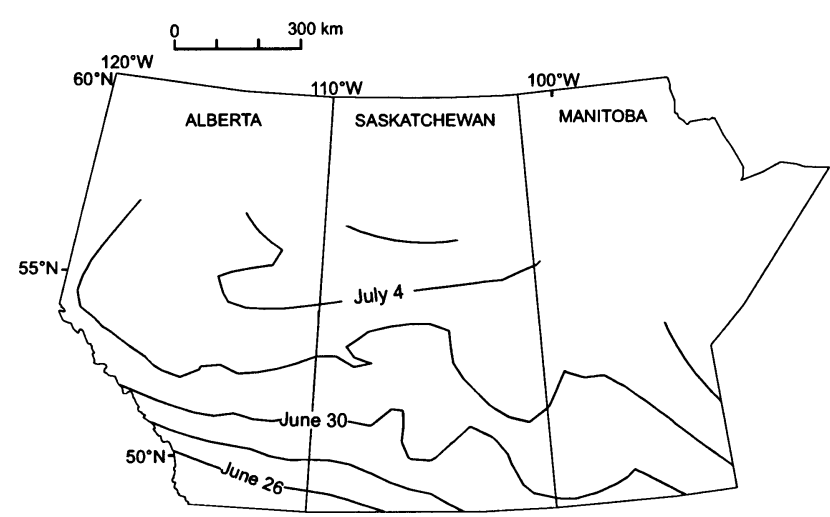

Fig. 4. Spatial distribution of average weighted centre dates over the Canadian Prairies (1905-96) (see text for weighted centre definition and calculation). Contour interval is $2 \mathrm{~d}$
M ay 2 to $31, \ldots$ August 2 to 31; a total of 94 periods). The $30 \mathrm{~d}$ or monthly time scale reduces the high degree of variability in daily and even weekly precipitation amounts while the moving window allows for between calendar month (e.g. mid May to mid J une) analyses. Fig. 3 provides the areally averaged temporal distribution of growing season precipitation on the Canadian Prairies for 1905-96. Each $30 \mathrm{~d}$ moving window amount is expressed as a percentage of the average (1905-96) total growing season precipitation. The graph shows that maximum precipitation normally occurs from approximately mid J une to early J uly. Several different methods have been used to analyze variability in the temporal distribution of precipitation for a given region. These range from simple statistics such as skewness and kurtosis (e.g. Harrington \& Cerveny 1989) to more advanced techniques like harmonic analysis (e.g. Sabbagh \& Bryson 1962). For the purpose of this study, variability in the temporal distribution of growing season precipitation is examined by calculating the weighted centre as follows:

$$
\text { Weighted Centre }=\sum_{i=1}^{94} P_{i} D_{i} / \sum_{i=1}^{94} P_{i}
$$

where $P=30 \mathrm{~d}$ precipitation total and $\mathrm{D}=30 \mathrm{~d}$ period within the growing season (i.e. May 1 to $30=1$, August 2 to $31=94$ ).

This procedure is well suited to the unimodal profile of Canadian Prairie growing season precipitation and is able to quantify shifts in the distribution relative to a particular growing season day. The weighted centre of the temporal distribution in Fig. 3 is cal culated to occur on J uly 1 . This date identifies the midpoint of the $30 \mathrm{~d}$ period in which precipitation is centred during the growing season. The spatial distribution of average weighted centre values over the Canadian Prairies is given in Fig. 4. The map shows a general south to north progression toward later dates, with southern Alberta having a centre on J une 26 and northern Saskatchewan on J uly 6 . This progression is likely attributable to the south to north advancement of the principal storm track through this region during J une and J uly as outlined by Chakravarti (1972).

On an annual basis, shifts in the weighted centre represent changes in the temporal distribution of precipitation within the growing season. For example, a shift to an earlier date indicates either more early growing season precipitation, less later growing season precipitation, or a combination of these 2 occurrences. For each growing season, the areally averaged weighted centre anomaly (in days) is calculated relative to the long-term average of J uly 1 . The time series (Fig. 5) shows considerable interannual and interdecadal variability with anomalies ranging from nearly - 9 d in 1908 to over +9 d in 1924 . To detect decadal 
scale fluctuations, statistical testing is employed on consecutive, non-overlapping intervals of 10, 15, 20, 25, and 30 yr (see Karl \& Riesbame 1984). Significant differences are provided in Table 1 . The dates refer to the initial year of the second period in question. For example, in the $20 \mathrm{yr}$ interval, 1925 refers to a significant difference in values between 1905-24 and 1925-44. Table 1 shows 1925, 1945, and 1970 are significant for the majority of the analyses. In addition, 1980 is significant for the $10 \mathrm{yr}$ interval. These 'change points' in weighted centre anomalies are also evident in Fig. 5. As a result, the temporal distribution of growing season precipitation is compared for the 5 periods 1905-24, 1925-44, 1945-69, 1970-79, and 1980-96 (Fig. 6a-d). Shading denotes $30 \mathrm{~d}$ precipitation values that are significantly different. The average weighted centre date and total growing season precipitation for each period are also provided.

Fig. 6a shows the temporal distribution was centred slightly earlier during 1925-44 as opposed to 1905-24, mainly due to significantly less precipitation later in the growing season. The first period showed considerably more interannual variability in weighted centres while the latter had consistently earlier values (see Fig. 5). Average total growing season precipitation was approximately $4.5 \%$ lower for the second period. The temporal distribution for 1945-69 was substantially later in comparison with 1925-44. Significant differences included less J une and more J uly-August precipitation in the latter period. The weighted centre anomalies were consistently later during the 1945-69 interval. The 1970s showed significantly more early growing season precipitation (Fig. 6c), with the weighted centre anomalies consistently negative for

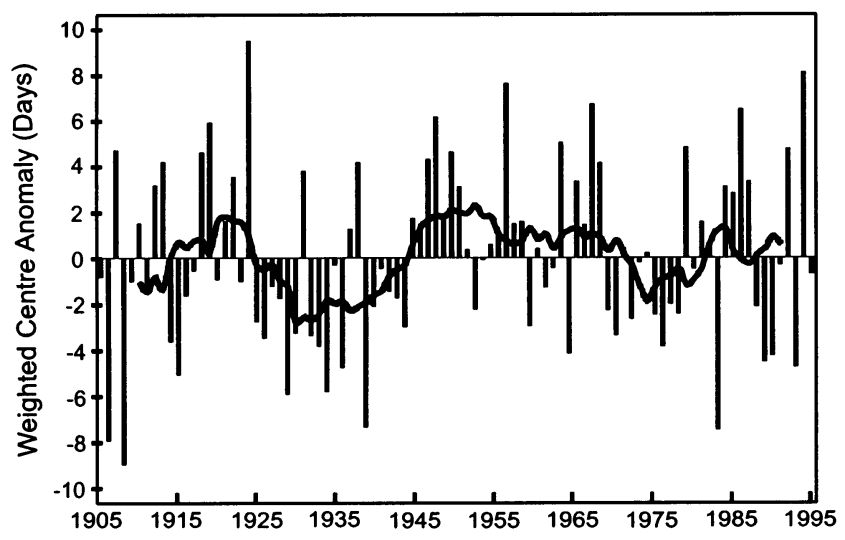

Fig. 5. Areally averaged weighted centre anomalies in the temporal distribution of $30 \mathrm{~d}$ growing season precipitation values on the Canadian Prairies. Anomalies are calculated relative to the 1905-96 average weighted centre, which occurs on approximately J uly 1 (see text for details). Solid line represents $10 \mathrm{yr}$ running mean
Table 1. Years in which significant differences (using the Student's t-test and Wilcoxon rank-sum test at the 5\% level) occur in the weighted centre anomalies shown in Fig. 5. Differences between consecutive, non-overlapping intervals of $10,15,20,25$, and $30 \mathrm{yr}$ are analyzed. Dates refer to the initial year of the second period in question

\begin{tabular}{|lllll|}
\hline $10 \mathrm{yr}$ & $15 \mathrm{yr}$ & $20 \mathrm{yr}$ & $25 \mathrm{yr}$ & $30 \mathrm{yr}$ \\
\hline 1926 & 1925 & 1925 & 1945 & 1945 \\
1945 & 1945 & 1945 & 1970 & \\
1970 & 1970 & 1965 & & \\
1980 & & & & \\
\hline
\end{tabular}

the entire decade (Fig. 5). Total growing season precipitation was substantially higher in comparison to all previous periods. Following 1979, the temporal distribution again shifted to later in the growing season. This was mainly attributable to less J une and more J uly-August precipitation. The 1980-96 period had considerably more interannual variability in the weighted centre anomalies. Average total growing season precipitation was very similar to the 1970 s.

Fig. 6 reveals that the significant differences in weighted centre anomalies in Fig. 5 reflected considerable changes in the temporal distribution of precipitation within the growing season. Furthermore, relatively small changes in these weighted centres represented marked differences in the distribution. For example, 1925-44 versus 1945-69 (Fig. 6b) had only a 5 d difference in the average weighted centre, with the former occurring on J une 28 and the latter on J uly 3 . However, this translated into a very large shift in the temporal distribution within the growing season which could potentially have had a large impact on several activities, including agriculture.

\section{AMOUNT OF GROWING SEASON PRECIPITATION}

Average monthly precipitation over the Prairies associated with the 5 periods outlined in Section 3 are presented in Table 2. Numbers in parentheses refer to the percentage change in precipitation from the previous period. On average (1905-96), J une receives the highest precipitation $(78.0 \mathrm{~mm})$ followed by July (70.1 mm), August (58.1 mm), and May (48.5 mm). For individual periods, precipitation during 1905-24 was near the long-term average for every month. From 1925-44, there were substantial decreases in J uly and August rainfall. The later precipitation distribution from 1945-69 was caused by a combination of decreases in both $M$ ay and J une, and large increases in July and especially August. The 1970s had very 

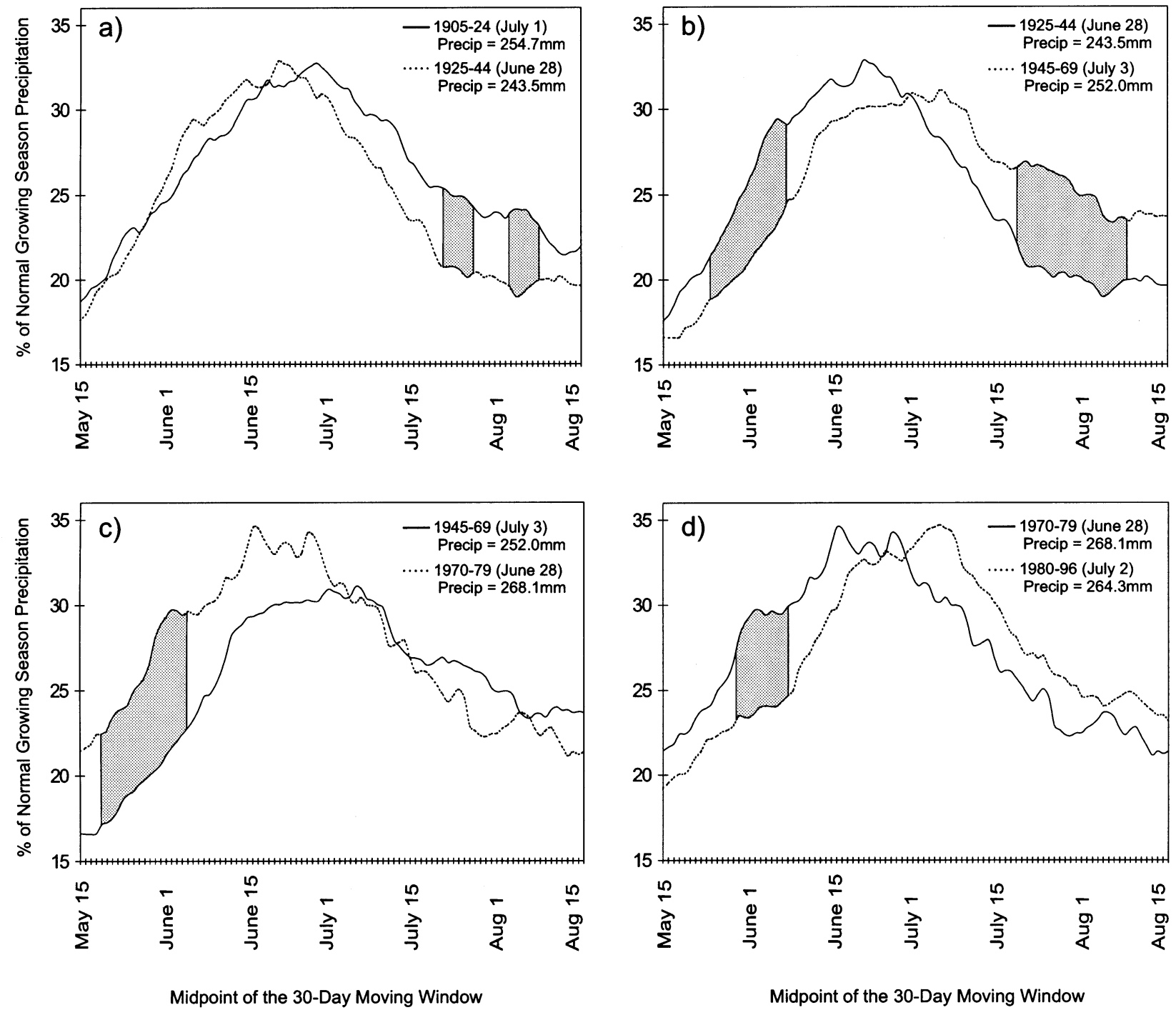

Fig. 6. Temporal distribution of $30 \mathrm{~d}$ moving window growing season precipitation on the Canadian Prairies for (a) 1905-24 vs 1925-44, (b) 1925-44 vs 1945-69, (c) 1945-69 vs 1970-79, and (d) 1970-79 vs 1980-96. Each 30 d precipitation amount is expressed as a percentage of average total growing season precipitation from 1905 to 1996. Dates refer to the midpoint of the $30 \mathrm{~d}$ moving window. Shading denotes periods when $30 \mathrm{~d}$ precipitation values are significantly different at the $5 \%$ level using the Student's t-test and Wilcoxon rank-sum test. Average weighted centre date (in parentheses) and total growing season precipitation for each period are also provided

large increases in May and J une, relatively no change in July, and a decrease in August. The higher early growing season values resulted in a substantial increase in total growing season precipitation. The final period showed decreases in May and June, accompanied by large increases in J uly and A ugust. In fact, J uly has replaced J une as the month of maximum precipitation.

Variability in monthly precipitation is further analyzed by examining the time series of areally averaged standardized precipitation anomalies for each month and the total growing season (Fig. 7a-e). May precipitation was higher for 1905-16, generally lower for
1917-73, and substantially increased for 1974-96. There is a significant difference in values between the latter 2 periods. J une showed substantial interannual but little interdecadal variability throughout the entire period. J uly had variable precipitation for 1905-16 followed by anomalously low values from approximately 1917 to 1947. Since then, there has been an increase in amounts especially during 1981-96. The difference between 1917-47 and 1948-96 is statistically significant. August is similar to J uly in that there were generally negative anomalies from around the mid 1910s to the mid 1940s. Since 1945, there has been considerable interannual variability. A significant difference exists 
Table 2. Average monthly precipitation $(\mathrm{mm})$ over the Canadian Prairies for the 5 periods shown in Fig. 6 . Numbers in parentheses refer to the percentage change in precipitation from the previous period. A verage values for the entire study period (1905-96) are also provided

\begin{tabular}{|lcccccc|}
\hline Month & $1905-24$ & $1925-44$ & $1945-69$ & $1970-79$ & $1980-96$ & $\begin{array}{c}\text { Average } \\
1905-96\end{array}$ \\
\hline May & 49.4 & $\begin{array}{c}47.6 \\
(-3.6 \%)\end{array}$ & $\begin{array}{c}44.1 \\
(-7.4 \%)\end{array}$ & $\begin{array}{c}55.9 \\
(+26.8 \%)\end{array}$ & $\begin{array}{c}50.5 \\
(-9.7 \%)\end{array}$ & 48.5 \\
J une & 77.8 & $\begin{array}{c}80.9 \\
(+4.0 \%)\end{array}$ & $\begin{array}{c}74.4 \\
(-8.0 \%)\end{array}$ & $\begin{array}{c}85.4 \\
(+14.8 \%)\end{array}$ & $\begin{array}{c}75.5 \\
(-11.6 \%)\end{array}$ & 78.0 \\
& & & & \\
July & 70.4 & 62.3 & 70.7 & 70.0 & 78.0 & 70.1 \\
& & $(-11.5 \%)$ & $(+13.5 \%)$ & $(-1.0 \%)$ & $(+11.4 \%)$ & \\
August & 57.0 & 52.6 & 62.1 & 56.4 & 61.0 & 58.1 \\
& & $(-7.7 \%)$ & $(+18.1 \%)$ & $(-9.2 \%)$ & $(+8.2 \%)$ & \\
Total & 254.7 & 243.5 & 252.0 & 268.1 & 264.3 & 254.8 \\
& & $(-4.4 \%)$ & $(+3.5 \%)$ & $(+6.4 \%)$ & $(-1.4 \%)$ & \\
& & & & & & \\
\hline
\end{tabular}

between 1914-45 and 1946-96. The time series of total growing season precipitation (Fig. 7e) indicates 3 distinct periods: above normal precipitation from 1905-16, anomalously low amounts during 1917-49, and generally higher precipitation from 1950-96. There are significant differences between 1905-16 and 1917-49, and, especially, between 1917-49 and 1950-96. The 1917-49 period had an average value of $237.5 \mathrm{~mm}$ while 1950-96 was $262.1 \mathrm{~mm}$ (a $10.4 \%$ increase).

In comparison with the temporal distribution, significant variations in monthly precipitation do not exactly match the periods shown in Fig. 5 and Table 2. This is expected since the weighted centres are influenced by a combination of varying precipitation amounts during the entire growing season. Nonetheless, the variability in monthly precipitation is reflected in the different distributions. The most notable occurred during July and August in the mid 1940s, when precipitation significantly increased. This resulted in a substantial shift in the temporal distribution of precipitation to later in the growing season, as evident in Fig. 6b. The earlier distribution of the 1970s (Fig. 6c) was influenced by the significant increase in May precipitation, as well as generally higher J une precipitation during this period. For 1980-96, the distribution again shifted to a later date. This was mainly attributable to a combination of lower J une (especially in the 1980s) and more J uly precipitation. Recall that average July precipitation was higher than J une during this period.

\section{ATM OSPHERIC CIRCULATION}

On a regional scale, Canadian Prairie growing season precipitation is mainly controlled by the circulation of the mid-troposphere (e.g. Dey 1982). Monthly $500 \mathrm{hPa}$ circulation patterns are therefore examined. Since reliable $500 \mathrm{hPa}$ data only extend back to 1946 , SLP patterns (for which data are available for the entire study period) are also analyzed. At each level, relationships with growing season precipitation are initially analyzed by examining differences in composite circulation and anomaly patterns associated with extreme dry and wet months (e.g. Keables 1989, Knox \& Lawford 1990). Based on these differences, synoptic scale atmospheric indices which best explain variations in monthly precipitation on the Prairies are developed. Variability in atmospheric circulation patterns are then inferred through time series analyses of the indices.

\subsection{Mid-tropospheric circulation}

Composite Northern Hemisphere $500 \mathrm{hPa}$ circulation patterns and anomalies associated with the 5 driest and 5 wettest Mays from 1946-96 (i.e. approximately the driest and wettest 10\%) are shown in Fig. 8. The dry composites are characterized by meridional flow over North America with an amplification of the climatological west coast ridge and a deepening of the trough over eastern Canada. The Canadian Prairies are located directly under, or on the eastern side of the, mid-tropospheric ridge. This results in drier than normal conditions due to the associated lower level divergence and subsidence and cyclonic systems being diverted north of the region. The anomalies over $N$ orth America are essentially opposite during wet periods. The west coast ridge is replaced by slight troughing while the eastern Canadian trough is displaced well to the east over the Atlantic. Anomalously wet $M$ ays are therefore associated with a west-east directed flow across the Prairies. This, along with the upper level troughing, results in a higher frequency of cyclonic and frontal activity over the Prairie region (Dey 1977). In very extreme wet cases (e.g. May 1977, not shown), the flow is also meridional with the ridge and trough positions opposite to dry situations. Composite J une circulation patterns and anomalies (not shown) are very similar to M ay in both the dry and wet cases. Similar processes therefore affect extreme precipitation conditions during both months.

Fig. 9 shows that the circulation associated with J uly dry periods is also meridional; however, amplifications in the ridge and trough are not as pronounced as in May and June. During July, there is a strong north- 

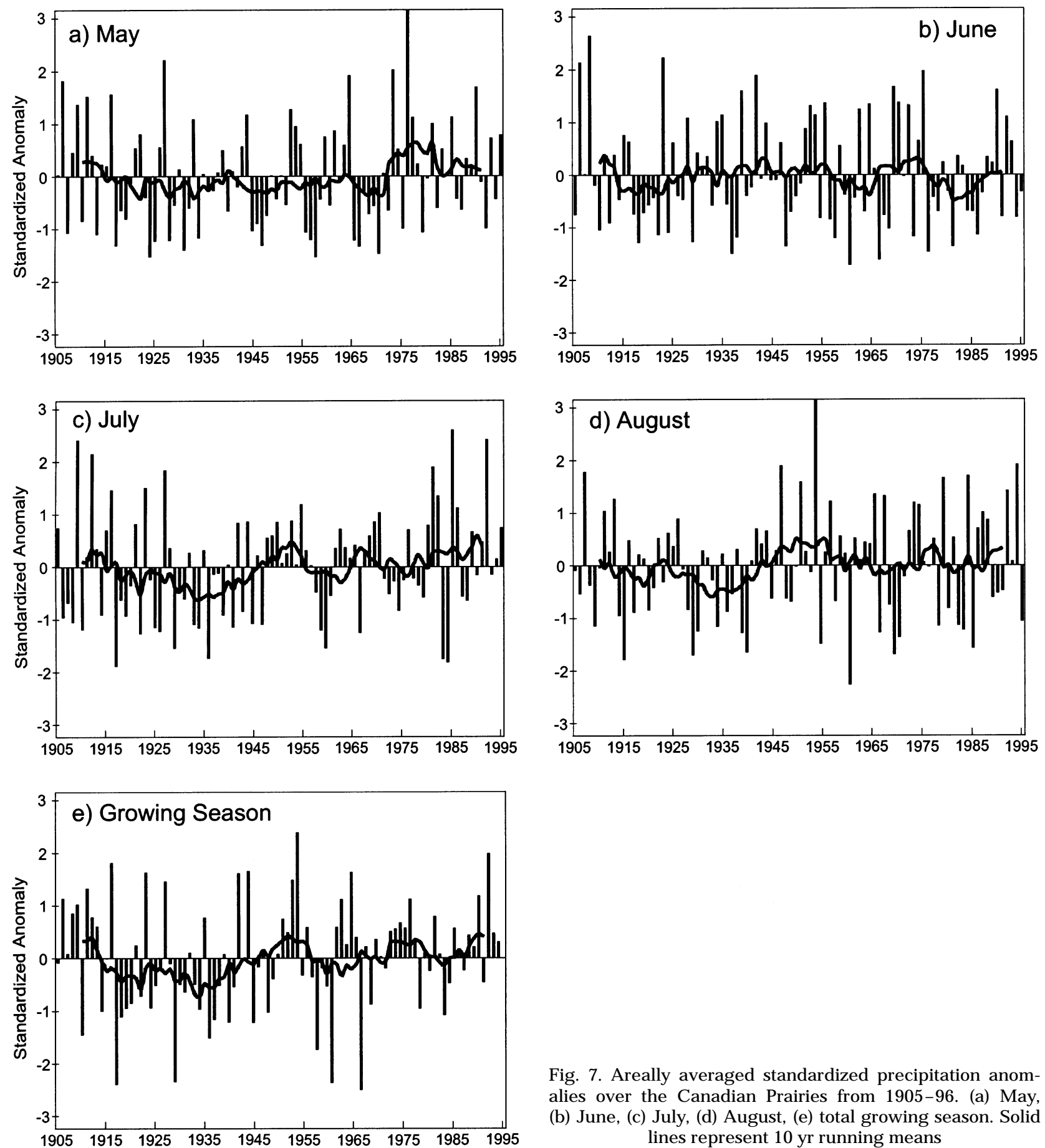

Fig. 7. Areally averaged standardized precipitation anomalies over the Canadian Prairies from 1905-96. (a) May, (b) J une, (c) July, (d) August, (e) total growing season. Solid lines represent $10 \mathrm{yr}$ running means

westerly directed flow over and to the north the Prairie region and relatively weaker flow to the south of the region. The Prairies are dry due to their location with respect to the mid-tropospheric ridging and the northwesterly flow which is likely associated with drier Arctic air. In addition, stronger (weaker) flow to the north (south) is representative of anticyclonic westerly shear vorticity and thus drier conditions over the study area.
J uly wet cases show a strong, west-east directed flow over the southern Prairies and central United States, while the northern Prairies exhibit a relatively weaker flow. The circulation is somewhat similar to M ay and $J$ une in that the west coast ridge disappears and the eastern trough is displaced towards the Atlantic. The anomalously wet periods are likely attributable to the southerly location of strong west-east directed flow 

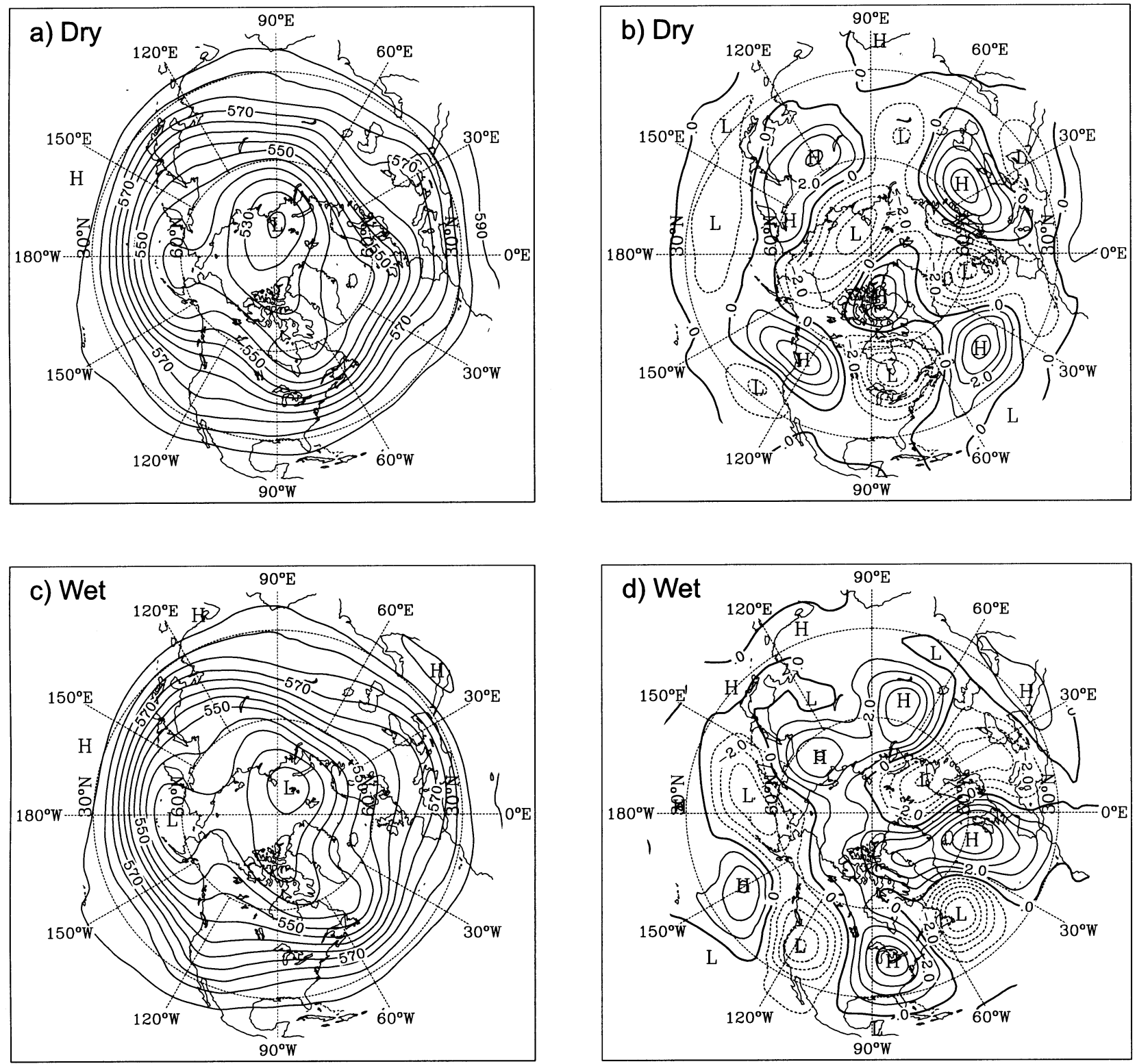

Fig. 8. Composite Northern Hemisphere 500 hPa circulation patterns associated with the 5 driest and 5 wettest Mays on the Canadian Prairies from 1946-96. (a) Circulation for dry cases, (b) anomalies for dry cases, (c) circulation for wet cases, (d) anomalies for wet cases. Contour interval is 5.0 dam (decametres) for the circulation maps and 1.0 dam for the anomalies. The dry composites include 1958, 1966, 1971, 1967, and 1947 and the wet include 1977, 1974, 1991, 1965, and 1953

which is representative of cyclonic westerly shear vorticity over the Prairie region. August (not shown) closely resembles J uly for both the dry and wet cases.

It is evident that the strength of the west coast ridge and eastern trough affects growing season precipitation during all months. The following atmospheric index describes this flow:

$\mathrm{MI}=\mathrm{Z}\left(45^{\circ} \mathrm{N}\right.$ to $\left.55^{\circ} \mathrm{N}, 120^{\circ} \mathrm{W}\right)-\mathrm{Z}\left(45^{\circ} \mathrm{N}\right.$ to $\left.55^{\circ} \mathrm{N}, 80^{\circ} \mathrm{W}\right)$ where $Z=$ average $500 \mathrm{hPa}$ value.
The latitude band $45^{\circ}-55^{\circ} \mathrm{N}$ approximately coincides with the Prairie study area while the longitudes $120^{\circ} \mathrm{W}$ and $80^{\circ} \mathrm{W}$ generally show the strongest anomalies in the monthly composite maps. Similar height difference methods have previously been used to analyze variations in mid-tropospheric flow associated with surface variables over various regions of North A merica (e.g. Skeeter 1990). Since this index provides a measure of the meridionality of flow significant to the Prairies, it is termed the Meridional Index (MI). Positive anomalies 

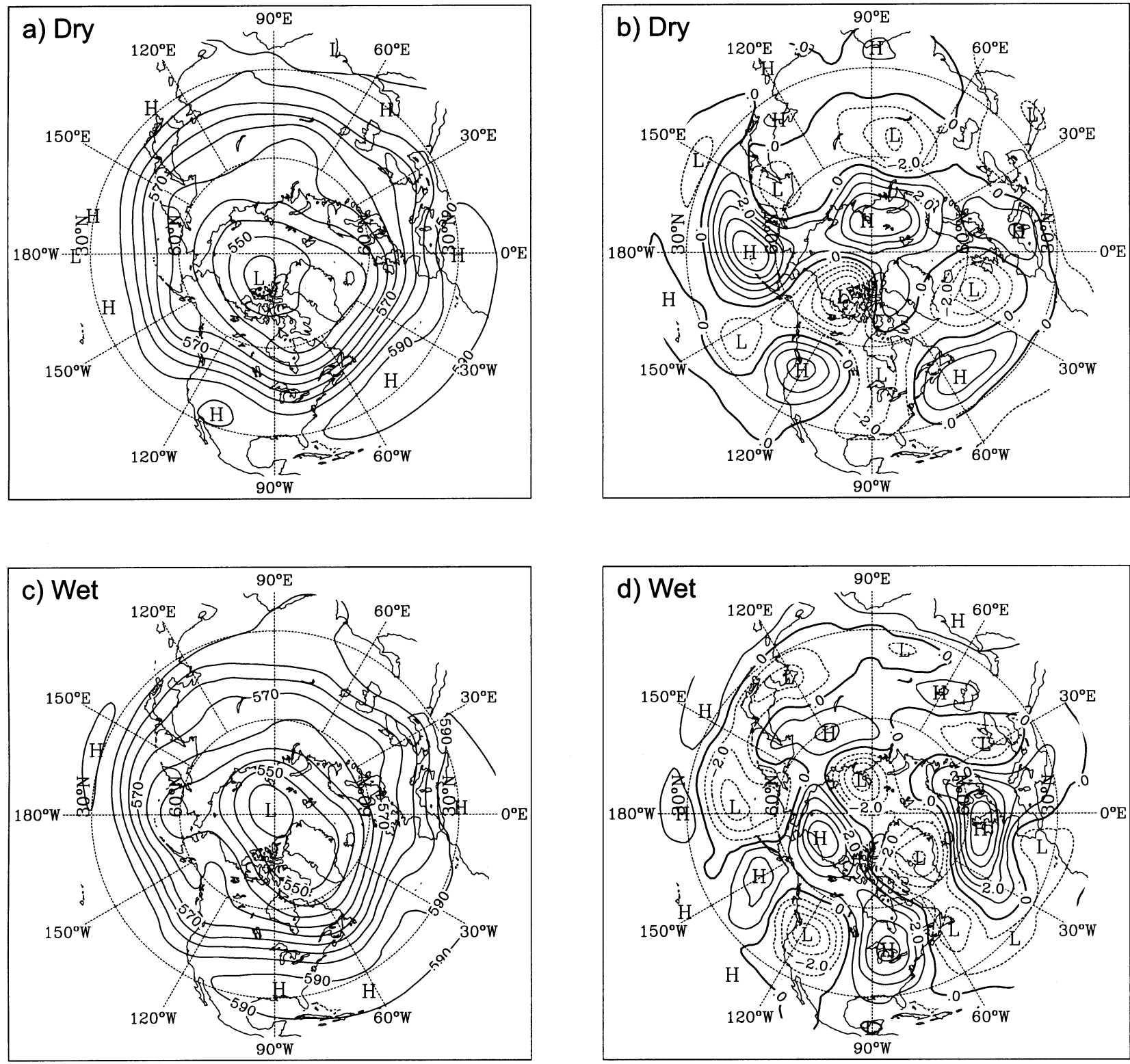

Fig. 9. Composite Northern Hemisphere $500 \mathrm{hPa}$ circulation patterns associated with the 5 driest and 5 wettest J ulys on the Canadian Prairies from 1946-96. (a) Circulation for dry cases, (b) anomalies for dry cases, (c) circulation for wet cases, (d) anomalies for wet cases. Contour interval is 5.0 dam for the circulation maps and 1.0 dam for the anomalies. The dry composites include 1985, 1984, 1960, 1967, and 1959 and the wet include 1986, 1993, 1982, 1983, and 1955

of $\mathrm{MI}$ represent stronger than normal meridional flow with an amplification of the western ridge, the eastern trough, or both (dry conditions). Negative anomalies are associated with a weakening of the ridge and trough and, thus, a more west-east directed flow over the Prairies (wet conditions). Large negative values also indicate meridional flow with opposite ridge and trough positions to positive values (extreme wet conditions).

The composite maps also suggest that differences in the strength of the westerly flow between the northern and southern regions of the Prairies affect precipitation, particularly later in the growing season. These differences are quantified using latitudinal pressure gradients from $120^{\circ} \mathrm{W}$ to $90^{\circ} \mathrm{W}$ (the approximate longitudinal extent of the study region) with the following index:

$$
\mathrm{ZI}=\mathrm{Grad}\left(50^{\circ} \mathrm{N} \text { to } 60^{\circ} \mathrm{N}\right)-\operatorname{Grad}\left(35^{\circ} \mathrm{N} \text { to } 45^{\circ} \mathrm{N}\right)
$$

where $\mathrm{Grad}=$ average $500 \mathrm{hPa}$ gradient from $120^{\circ} \mathrm{W}$ to $90^{\circ} \mathrm{W}$. 
Table 3. Correlation coefficients between meridional (MI) and zonal (Zl) $500 \mathrm{hPa}$ atmospheric indices and monthly growing season precipitation on the Canadian Prairies (1946-96). Multiple regression correlation coefficients and percentage of variance explained using both $\mathrm{MI}$ and $\mathrm{ZI}$ are also provided. Correlations significant at the $1 \%$ level are denoted by an asterisk

\begin{tabular}{|lcccc|}
\hline Month & MI & ZI & $\begin{array}{c}\text { Multiple } \\
\text { correlation }\end{array}$ & $\begin{array}{c}\text { Variance } \\
\text { explained (\%) }\end{array}$ \\
\hline May & $-0.727^{*}$ & -0.263 & $0.756^{*}$ & 57.1 \\
June & $-0.651^{*}$ & -0.309 & $0.670^{*}$ & 44.9 \\
July & $-0.500^{*}$ & $-0.493^{*}$ & $0.674^{*}$ & 45.5 \\
August & $-0.379^{*}$ & $-0.637^{*}$ & $0.741^{*}$ & 54.9 \\
\hline
\end{tabular}

This index measures characteristics of the west-east flow and is thus termed the Zonal Index (ZI). The 2 latitudinal gradients of $50^{\circ}-60^{\circ} \mathrm{N}$ and $35^{\circ}-45^{\circ} \mathrm{N}$ are chosen since they show the highest correlations with Prairie precipitation. The former is negatively correlated while the latter has a positive correlation. An examination of circulation maps associated with ZI reveals that positive anomalies represent strong flow in the north $\left(50^{\circ}-60^{\circ} \mathrm{N}\right)$ and weak flow in the south $\left(35^{\circ}-45^{\circ} \mathrm{N}\right)$ (dry conditions) while negative anomalies are indicative of small differences in the strength of flow between these 2 regions. Large negative values signify weak flow to the north and strong to the south (extreme wet conditions). As alluded to previously, the difference in gradients between these 2 latitude bands is representative of westerly shear vorticity over the Prairie region. Positive anomalies are associated with strong anticyclonic shear vorticity, negative anomalies with weak vorticity, and large negative anomalies with cyclonic shear vorticity.

Table 3 presents correlation coefficients between the 2 atmospheric indices and monthly precipitation on the Prairies for the period 1946-96. Multiple regression coefficients and percentage of variance explained using both $\mathrm{MI}$ and $\mathrm{ZI}$ are also provided. All MI values are significantly negative, indicating that during the entire growing season, positive indices (strong ridging over western and troughing over eastern (anada) are associated with lower precipitation and vice versa. The values, however, decrease in strength as the growing season progresses. For $\mathrm{ZI}$, all values are also negative but only J uly and August are significant. The negative correlation indicates that stronger (weaker) westerly flow to the north (south) of the Prairies is associated with lower precipitation and vice versa. Whereas the strength of the relationships associated with $\mathrm{MI}$ decreases from May to August, that associated with ZI increases. M ultiple regression shows that $57.1 \%$ of the variance in $\mathrm{M}$ ay precipitation is explained using both indices. However, this is not a vast improvement from using only $\mathrm{MI}$ and, thus, MI alone is likely a sufficient indicator. J une is similar to M ay except that a smaller portion of the variance is explained. For July and August, the regression analysis suggests that both indices are important.

The above suggests a difference in circulation patterns associated with precipitation variability during the early (May-J une) and late (J uly-August) periods of the growing season. It is evident from Figs. $8 \& 9$ that the same general wave orientations exist for both dry and wet situations thus explaining the significant correlations with $\mathrm{MI}$ during the entire growing season. However, Table 3 also suggests that, as the growing season progresses, the degree of meridionality becomes less important. Near the beginning of J uly, climatological changes in mid-tropospheric circulation patterns over North America include a strengthening of the mean ridge over the western United States (due to strong continental heating over the Great Plains) and a resultant northward shift in atmospheric pressure systems (e.g. Harman 1991). During J uly and August, other meridional indices (designed to account for this northward shift) were formulated, but did not improve the correlations with Prairie precipitation. It therefore appears that ZI (which represents shear vorticity changes over the Prairies) has a stronger effect on precipitation later in the growing season. Relationships between $\mathrm{ZI}$ and the climatological shift in mean circulation during July and August are beyond the scope of this paper and require further analysis.

An example of the relationships in Table 3 is given in Fig. 10, which compares May precipitation and $\mathrm{MI}$ ( $r=-0.727)$. The inverse of $\mathrm{MI}$ is plotted for easier comparison. The graph shows a very good correspondence between the 2 variables. As with $\mathrm{M}$ ay precipitation, MI values for 1974-96 were significantly dif-

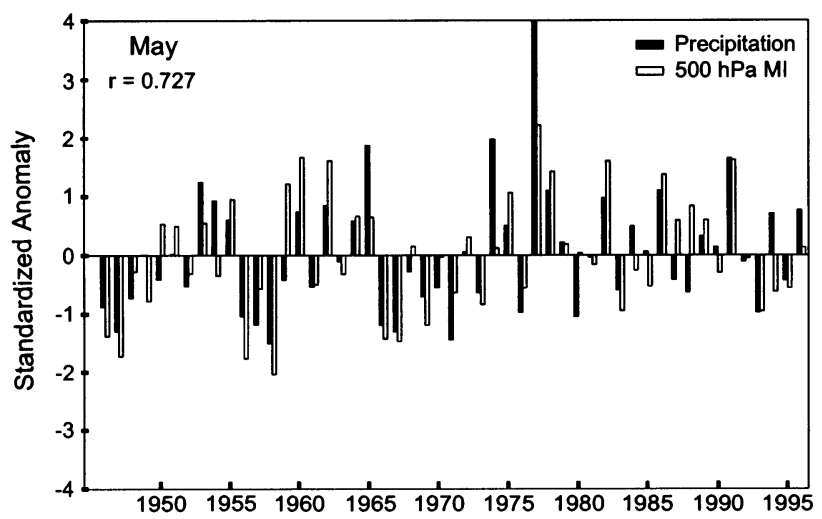

Fig. 10. May precipitation versus the $500 \mathrm{hPa}$ Meridional Index (MI) for 1946-96. The inverse of the original MI is shown for easier comparison 

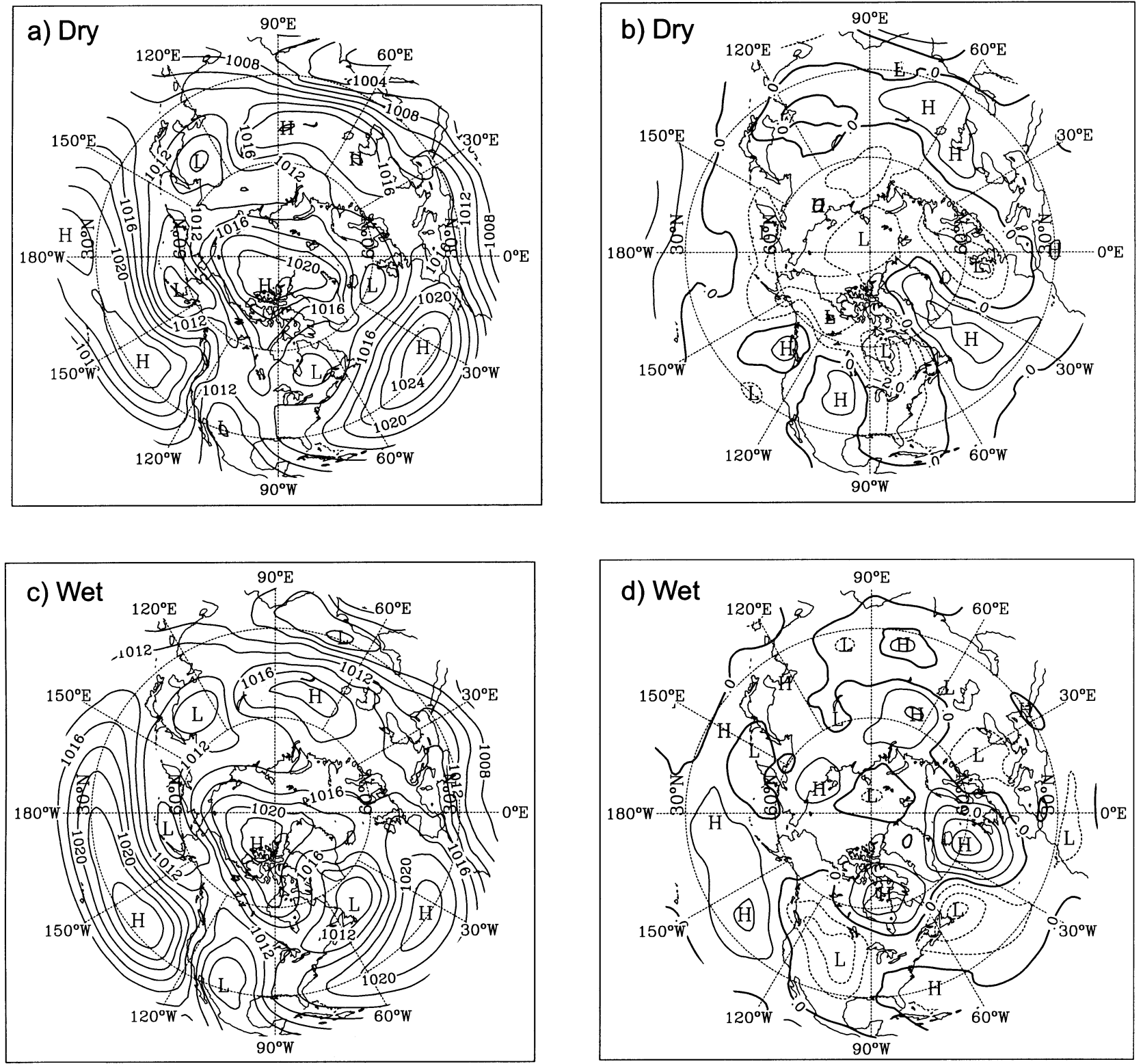

Fig. 11. Composite Northern Hemisphere SLP patterns associated with the 5 driest and 5 wettest M ays on the Canadian Prairies from 1905-93. (a) Circulation for dry cases, (b) anomalies for dry cases, (c) circulation for wet cases, (d) anomalies for wet cases. Contour interval is $2.0 \mathrm{mb}$ for the circulation maps and $1.0 \mathrm{mb}$ for the anomalies. The dry composites include 1958, 1966, 1924, 1928, and 1971 and the wet include 1977, 1927, 1974, 1906, and 1991

ferent from the rest of the series (1946-73). This indicates a tendency for less ridging (troughing) over western (eastern) North America since 1974. An examination of the other significant $500 \mathrm{hPa}$ indices in Table 3 (not shown) also shows good agreement with monthly precipitation, especially during extreme dry and wet periods. The time series of these indices had no significant decadal variations, which also complies with June, July, and August precipitation for 1946-96.

\subsection{SLP circulation}

Composite Northern Hemisphere SLP maps for extreme dry and wet Mays are given in Fig. 11. The main difference in circulation includes a much stronger low pressure over the continental United States which extends into the Prairies during wet cases. In addition, both the high pressure ridge extending from the Arctic and the low pressure over eastern Canada are located further east in comparison with dry 

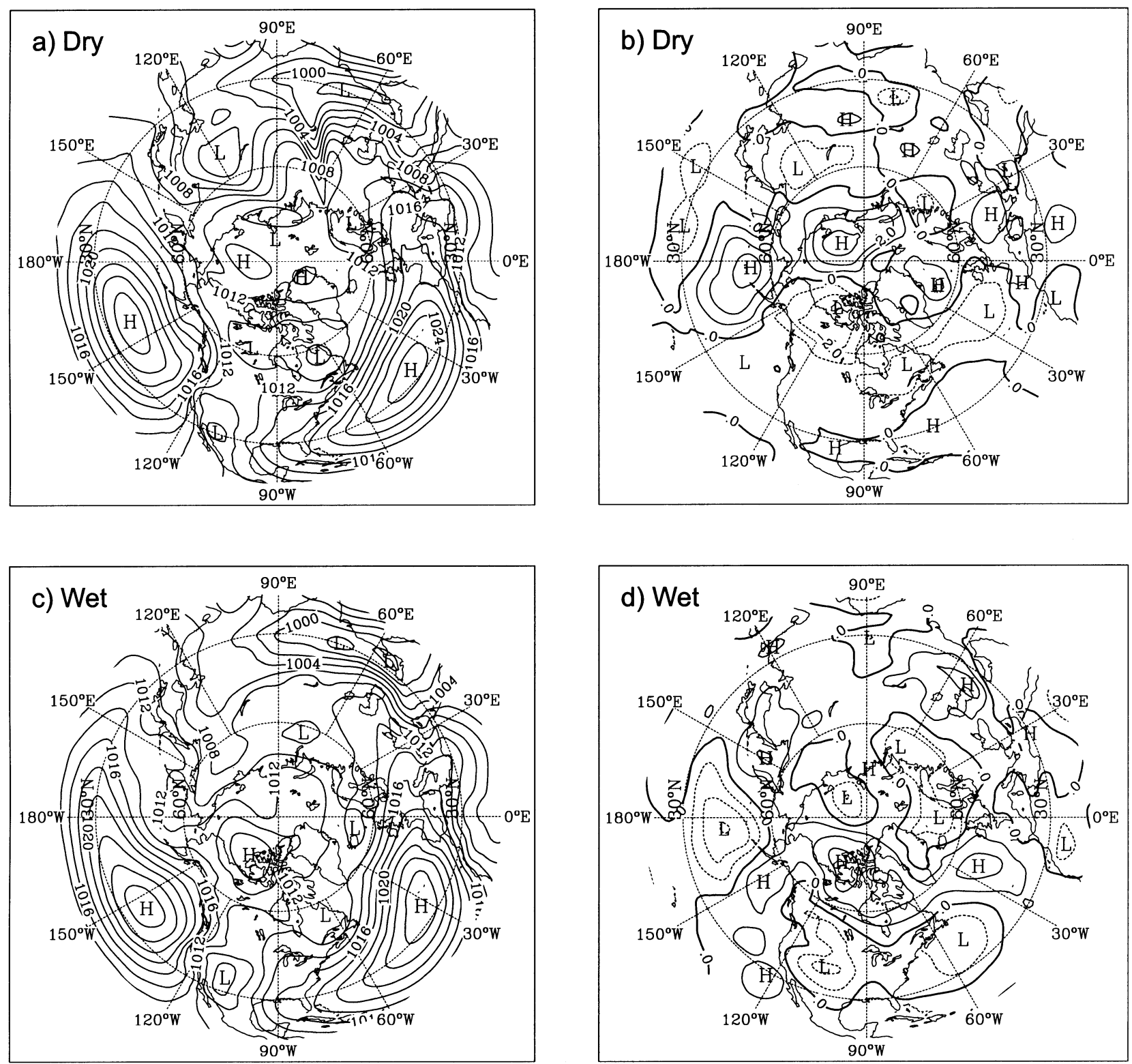

Fig. 12. Composite Northern Hemisphere SLP patterns associated with the 5 driest and 5 wettest J ulys on the Canadian Prairies from 1905-93. (a) Circulation for dry cases, (b) anomalies for dry cases, (c) circulation for wet cases, (d) anomalies for wet cases. Contour interval is $2.0 \mathrm{mb}$ for the circulation maps and $1.0 \mathrm{mb}$ for the anomalies. The dry composites include 1917, 1936, 1985, 1984, and 1929 and the wet include 1986, 1993, 1909, 1912, and 1982

Mays. These differences are clearly evident in the anomaly maps in Fig. 11b,d. The circulation patterns result in a more southerly flow of moist air into the Prairie region during wet periods and a weak northerly flow of drier air during dry periods. J une SLP (not shown) closely resembles $M$ ay with only slight differences in the strength of the anomalies.

J uly and August SLP patterns are very similar and, therefore, only J uly is shown here (Fig. 12). For these months, there is also a difference in the strength and northward extension of the continental low between dry and wet situations; however, it is slightly less pronounced than in May and June. During July and August, large anomalies occur to the north of the Prairie region where lower (higher) pressure is associated with dry (wet) cases. These anomalies are a reflection of a stronger and more westward extended eastern Canadian low during dry periods, and a welldeveloped high pressure over the Arctic during wet periods. For both the dry and wet composites, the cir- 
culation patterns in Fig. 12a,c indicate relatively weak flow affecting the Prairies. This includes a weak northwesterly flow into the region during dry periods and a weak southerly flow for wet periods. There are, however, fairly pronounced differences in the signs of the anomalies near the study area. In particular, negative (positive) anomalies are located to the north and positive (negative) anomalies to the south of the region in association with dry (wet) months. The patterns correspond to a westerly (easterly) surface wind anomaly over the Prairies.

The above shows that the strength and/or displacement of the continental low pressure over the United States, the high pressure over the Arctic, and the eastern Canadian low affect Canadian Prairie precipitation during the entire growing season. However, it appears that changes in the mean position of the high pressure and eastern Canadian low between early and late periods of the growing season result in differences in the location of the strongest anomalies relative to the Prairies. They are generally over and to the east of the Prairie region during $M$ ay and $J$ une and over and to the north of the Prairies during July and August. Atmospheric indices are developed to describe these anomalous surface flow characteristics over the Prairies:

$M I_{S L P}=P\left(45^{\circ} \mathrm{N}\right.$ to $\left.55^{\circ} \mathrm{N}, 100^{\circ} \mathrm{W}\right)-\mathrm{P}\left(45^{\circ} \mathrm{N}\right.$ to $\left.55^{\circ} \mathrm{N}, 80^{\circ} \mathrm{W}\right)$

$Z I_{\text {SLP }}=P\left(50^{\circ} \mathrm{N}, 120^{\circ} \mathrm{W}\right.$ to $\left.90^{\circ} \mathrm{W}\right)-\mathrm{P}\left(60^{\circ} \mathrm{N}, 120^{\circ} \mathrm{W}\right.$ to $\left.90^{\circ} \mathrm{W}\right)$

where $\mathrm{P}=$ average SLP value.

For $\mathrm{MI}_{\mathrm{SLP}}$, positive anomalies correspond to higher pressure over the Prairies and lower pressure at $80^{\circ} \mathrm{W}$ (a northerly flow into the Prairies). This is indicative of either a weaker low pressure over the continental United States, a westward displacement of both the high pressure ridge and eastern Canadian low, or a combination of these 2 occurrences. Negative $\mathrm{MISLP}_{\text {SLP }}$ anomalies correspond to opposite conditions and thus a southerly flow into the Prairie region. Positive anomalies of $\mathrm{ZI}_{\text {SLP }}$ indicate higher values over the southern Prairies (at $50^{\circ} \mathrm{N}$ ) and lower values to the north of the Prairies (at $60^{\circ} \mathrm{N}$ ) (i.e. anomalous westerly flow). As with $\mathrm{MI}_{\text {SLP, }}$, positive $\mathrm{ZI}_{\text {SLP }}$ are also indicative of a weaker continental low pressure over the United States. They also suggest a stronger and more westward extended eastern Canadian low. Negative $\mathrm{ZI}_{\text {SLP }}$ correspond to either a stronger and more northward extended continental low, a weaker eastern Canadian low, a well-developed high pressure to the north of the Prairies, or a combination of these events.

Correlation coefficients between the SLP indices and monthly precipitation are provided in Table 4. Regarding $\mathrm{MI}_{\mathrm{SLP}}$, only $\mathrm{M}$ ay and J une are significant (negative). Every growing season month has a significantly negative relationship with $\mathrm{ZI}_{\text {SLP. }}$. The coefficients are
Table 4. Correlation coefficients between meridional $\left(\mathrm{MI}_{\mathrm{SLP}}\right)$ and zonal $\left(\mathrm{ZI}_{\mathrm{SLP}}\right)$ SLP indices and monthly growing season precipitation on the Canadian Prairies (1905-93). Multiple regression correlation coefficients and percentage of variance explained using both $\mathrm{MI}_{\text {SLP }}$ and $\mathrm{ZI}_{\text {SLP }}$ are also provided. Correlations significant at the $1 \%$ level are denoted by an asterisk

\begin{tabular}{|lllcc|}
\hline Month & MI & ZI & $\begin{array}{c}\text { Multiple } \\
\text { correlation }\end{array}$ & $\begin{array}{c}\text { Variance } \\
\text { explained (\%) }\end{array}$ \\
\hline May & $-0.550^{*}$ & $-0.348^{*}$ & $0.660^{*}$ & 43.6 \\
June & $-0.529^{*}$ & $-0.463^{*}$ & $0.663^{*}$ & 43.9 \\
July & -0.202 & $-0.400^{*}$ & $0.453^{*}$ & 20.5 \\
August & -0.023 & $-0.450^{*}$ & $0.457^{*}$ & 20.9 \\
\hline
\end{tabular}

similar in magnitude, with J une and A ugust having the highest values. The significant values for both $\mathrm{MI}_{\text {SLP }}$ and $\mathrm{ZI}_{\mathrm{SLP}}$ indicate that changes in the strength and/or location of the continental low pressure over the United States, the high pressure over the Arctic, and the eastern Canadian low influence Canadian Prairie precipitation during the entire growing season. The large differences between May-June and JulyAugust $\mathrm{MI}_{\mathrm{SLP}}$ are likely, as alluded to previously, attributable to changes in the mean location of the high pressure over the Arctic and eastern Canadian low between early and late periods of the growing season. Multiple regression using both indices describes a considerable portion of the variance in $\mathrm{M}$ ay and J une precipitation (nearly $44 \%$ ); however, only slightly more than $20 \%$ is explained for J uly and August. The lower variance may be attributable to the occurrence of localized thunderstorms (i.e. convective precipitation) which are normally more frequent later in summer (Longley 1972).

Time series of the significant SLP indices in Table 4 generally compare well with the monthly precipitation series in Fig. 7. For instance, during $\mathrm{M}$ ay, $\mathrm{MI}_{\text {SLP }}$ and $\mathrm{ZI}_{\text {SLP }}$ were inversely related to precipitation with lower index values for 1905-16, generally higher during 1917-73, and lower again for 1974-93. As with precipitation, the 1917-73 and 1974-93 periods were significantly different for both indices. No significant decadal variations occurred in any of the June indices. The $\mathrm{ZI}_{\text {SLP }}$ values, however, show a distinct pattern for both July and August (Fig. 13a,b, the inverse of $\mathrm{ZI}_{\text {SLP }}$ is plotted for easier comparison with precipitation). In each month, there appeared to be 3 different periods: anomalous easterly flow for 1905-17, westerly from 1918-63, and easterly from 1964 to the present. As expected, both $\mathrm{ZI}_{\mathrm{SLP}}$ series had several significant differences between these various periods. Those with the highest significance included 1905-17 versus 1918-63, and 1918-63 ver- 
sus 1964-93 for J uly; and 1905-14 versus 1915-62, and 1915-62 versus 1963-93 for August. The $\mathrm{ZI}_{\text {SLP }}$ values resembled J uly and August precipitation (Fig. 7c,d), particularly on decadal scales. The generally low rainfall amounts between the mid 1910s and the mid 1940s were associated with anomalous westerly flow during both months. Since the early 1960s, precipitation has been generally higher especially during July. This period was associated with an anomalous easterly surface flow.

Recall that $\mathrm{ZI}_{\mathrm{SLP}}$ is influenced by changes in continental low pressure over the United States, the high pressure over the Arctic, and the eastern Canadian low. Fig. 14 shows the J uly time series of standardized SLP anomalies for individual grid points representative of these 3 surface pressure systems. The most dramatic change involved a substantial lowering in surface pressure over the continental United States from approximately the mid 1970s to the present (Fig. 14a). These lower pressures likely contributed to the recent increase in July precipitation over the Prairies (Fig. 7c). On the other hand, the generally higher precipitation for 1905-17 appeared to be influenced by a combination of anomalously strong high pressure over the Arctic (Fig. 14c) and an anomalously weak (or eastward displaced) eastern Canadian low (Fig. 14b). The lower rainfall amounts from the mid 1910s to mid 1940s were associated with a reversal in the strength of these 2 pressure systems. During both of these earlier periods, there was relatively no change in the strength of the continental low over the United States. August SLP (not shown) closely resembled July for all 3 grid points. The above strongly suggests that the significant interdecadal variability in later growing season precipita- tion on the Canadian Prairies was influenced by decadal variations in surface pressure patterns over North America. The series in Fig. 14 also indicate that precipitation variability earlier this century was affected by variations in the high pressure over the Arctic and the eastern Canadian low, while more recent changes have been influenced by the continental low over the United States. Further analysis reveals that the significant increase in May precipitation during the early 1970s was also associated with a general deepening of the continental low over the United States (not shown). However, the influence was not as prominent as in J uly and August.

In summary, the analysis of atmospheric circulation shows several significant relationships between the defined indices at the $500 \mathrm{hPa}$ and surface levels, and monthly precipitation over the Prairies. As with precipitation amounts, significant variations in the circulation indices do not exactly match the temporal distributions in Figs. $5 \& 6$, and Table 2. There are, however, several characteristics of the monthly indices evident in the precipitation distributions. For example, the positive anomalies of $\mathrm{ZI}_{\mathrm{SLP}}$ for 1925-44 likely contributed to the deficit in J uly and August precipitation, thus influencing the 2 distributions in Fig. 6b. The significant increase in May precipitation during the early 1970s was accompanied by a significant decrease in both M I indices (i.e. less meridional circulation). This contributed to the earlier precipitation shift during the 1970s (Fig. 6c). Additionally, the increase in J uly precipitation during 1980-96 was associated with lower ZI values at the $500 \mathrm{hPa}$ and especially the SLP levels (Fig. 13a), presumably due to a significant strengthening of the continental low pressure over the United States (Fig. 14a).
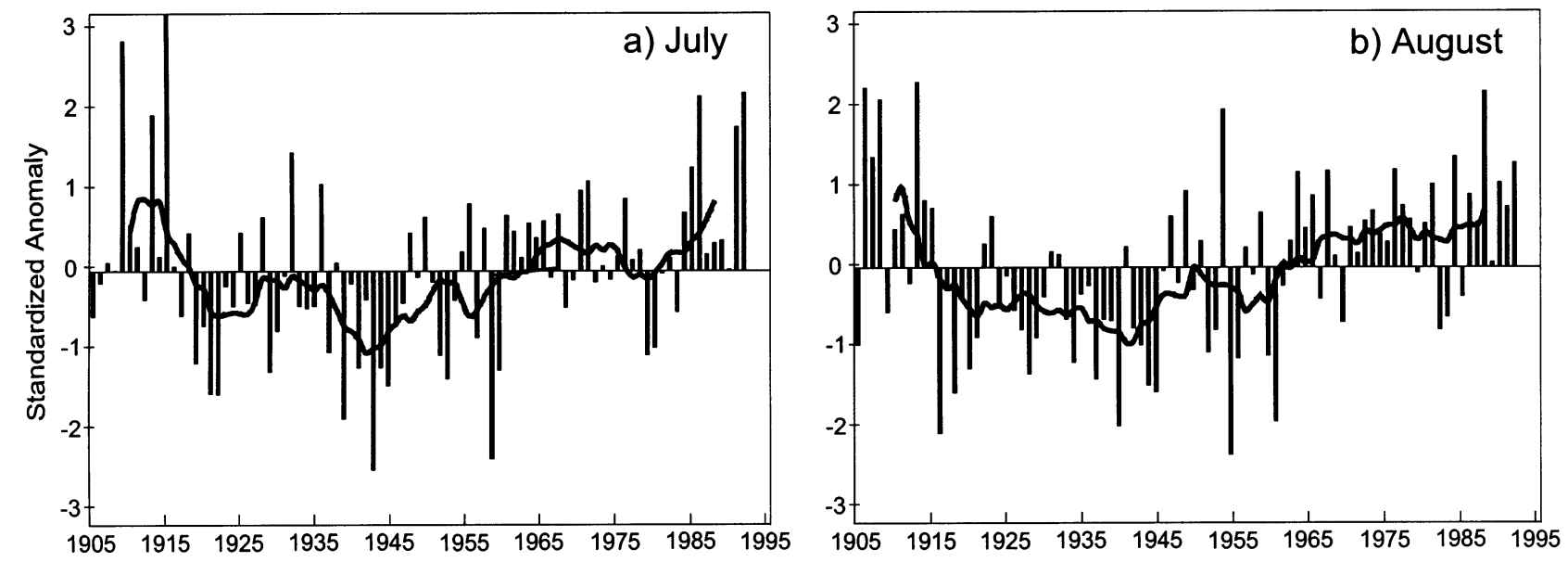

Fig. 13. SLP zonal indices ( $Z \mathrm{I}_{\mathrm{SLP}}$ ) for 1905-93. (a) J uly, (b) August. The inverse of the original $\mathrm{ZI} \mathrm{ILP}_{\mathrm{S}}$ values is shown for easier comparison with precipitation. Solid lines represent $10 \mathrm{yr}$ running means 

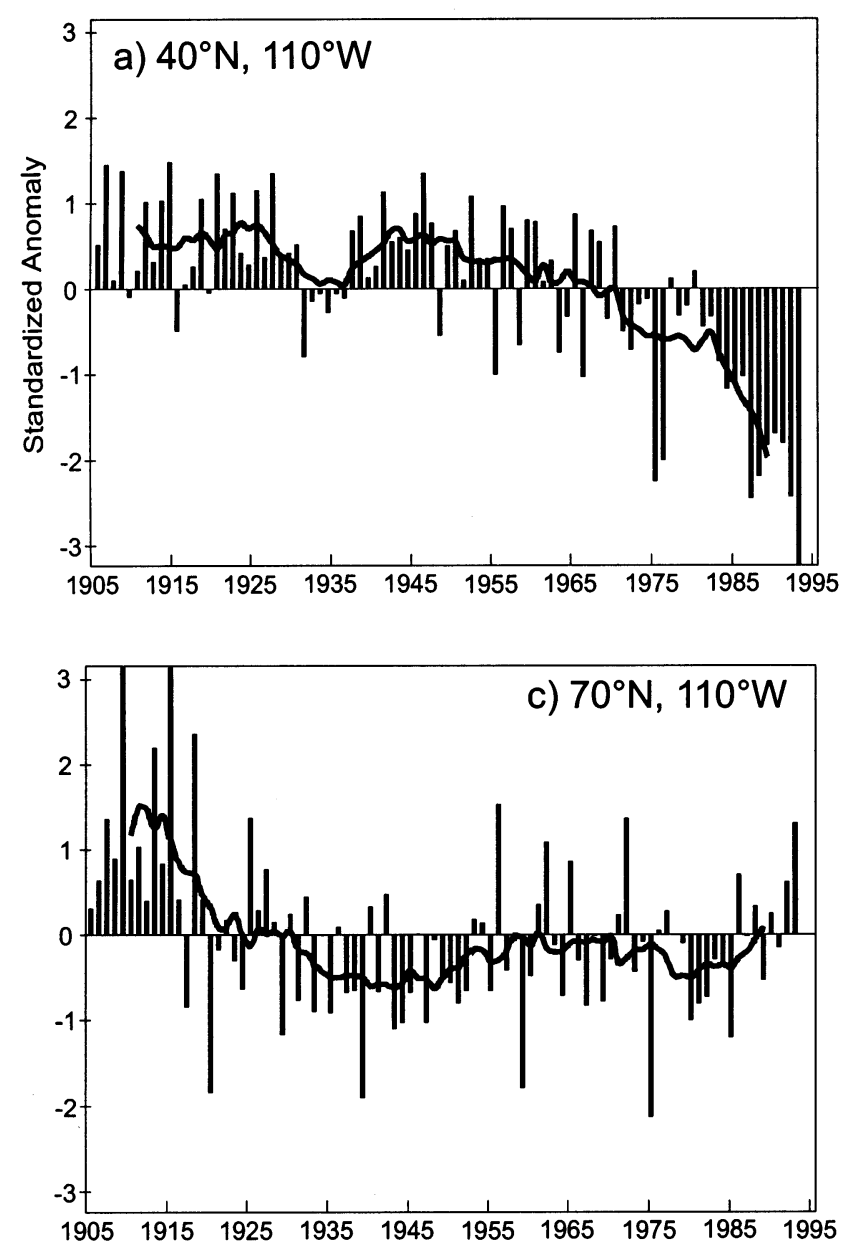

\section{DISCUSSION AND CONCLUDING REMARKS}

This analysis identifies significant interdecadal variability in the temporal distribution and amount of growing season precipitation on the Canadian Prairies for the period 1905-96. In terms of impacts to the Prairies (and particularly, to agriculture), the most critical factor is still the amount of precipitation. However, the temporal distribution within the growing season is also important. The 1930s and 1980s are often cited as the 2 worst drought (including crop yield) decades on the Prairies this century (e.g. M aybank et al. 1995). On average, the 1980s had almost $10 \%$ more total growing season precipitation than the 1930s. The temporal distribution (Fig. 15) shows similar precipitation during the early growing season, but the 1980s had significantly more rainfall in late J uly and August. A likely reason for low crop yields during the 1980s was the majority of precipitation came too late to aid in the growth of crops. Conversely, the 1930s drought was mainly attributable to very low precipitation amounts

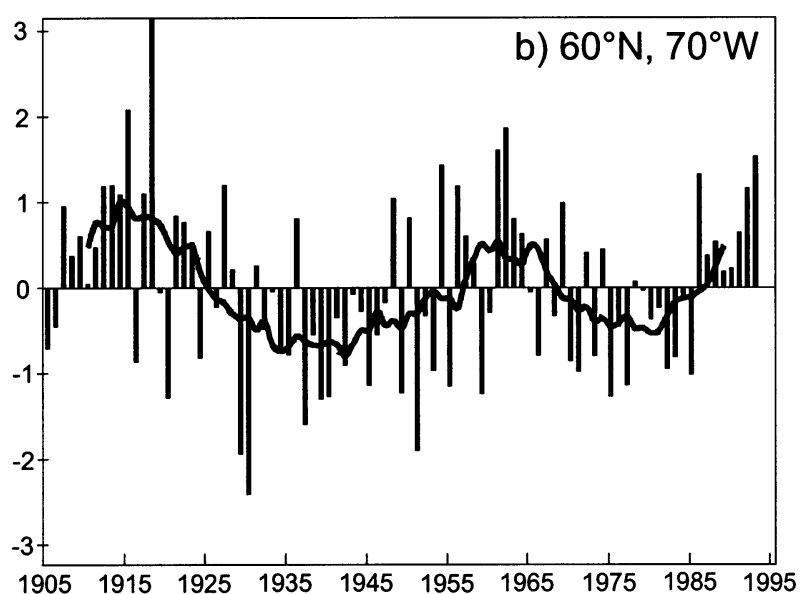

Fig. 14. J uly standardized SLP anomalies (1905-93) representative of surface pressure systems affecting growing season precipitation on the Canadian Prairies. (a) $40^{\circ} \mathrm{N}, 110^{\circ} \mathrm{W}$ (continental low pressure over the United States), (b) $60^{\circ} \mathrm{N}$, $70^{\circ} \mathrm{W}$ (eastern Canadian low pressure), (c) $70^{\circ} \mathrm{N}, 110^{\circ} \mathrm{W}$ (high pressure over the Arctic). Solid lines represent $10 \mathrm{yr}$ running means

during the entire growing season, especially J uly and A ugust. Further analysis reveals that another factor in the 1980s drought was considerably less non-growing season precipitation in comparison to the 1930s. The reduced soil moisture recharge combined with low early growing season precipitation contributed to low crop yields. Non-growing season climate can also impact the Prairies and therefore requires investigation. Another example of the importance in temporal distribution includes the 1970s (see Fig. 6d), which experienced very high crop production even though total growing season precipitation amounts were similar to the 1980s. The higher yields were likely due to the abundance of early growing season precipitation. Therefore, even though there appears to be more total growing season precipitation on the Prairies in recent years (Fig. 7e), the temporal distribution requires consideration since it can have significant impacts on activities such as agriculture.

Factors other than precipitation are important in the growing season climate of the Canadian Prairies. A 


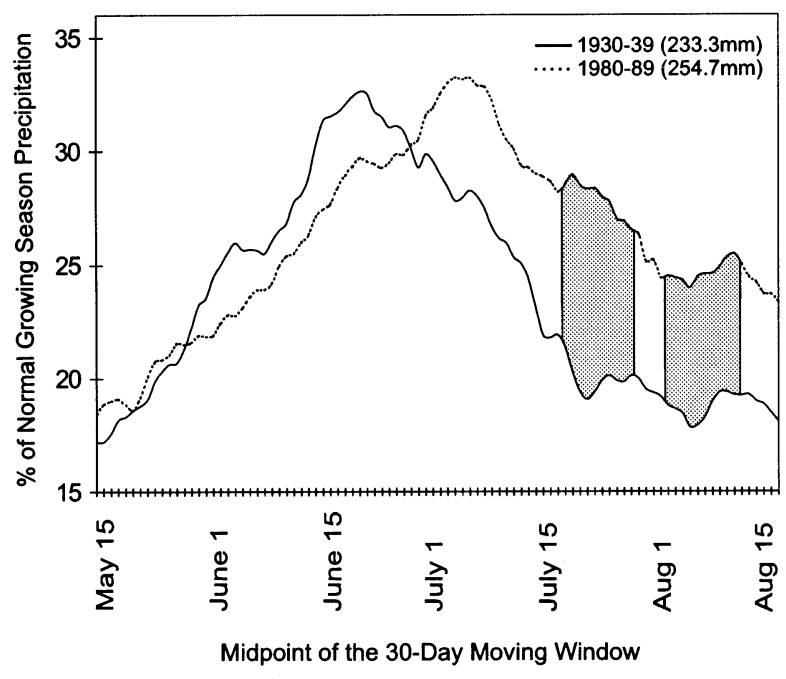

Fig. 15. Temporal distribution of $30 \mathrm{~d}$ moving window growing season precipitation on the Canadian Prairies for 1930-39 vs 1980-89. Each $30 \mathrm{~d}$ precipitation amount is expressed as a percentage of average total growing season precipitation from 1905 to 1996. Dates refer to the midpoint of the $30 \mathrm{~d}$ window. Shading denotes periods when $30 \mathrm{~d}$ precipitation values are significantly different at the $5 \%$ level using the Student's t-test and Wilcoxon rank-sum test. Total growing season precipitation (in parentheses) for each period is also provided

recent study by Bootsma (1994) indicated that, during the last century, several Canadian Prairie stations have shown an increase in the length of the growing season, a higher number of growing degree days, and significant increases in J uly air temperatures. Furthermore, predictions of future growing season climate on the Prairies suggest further increases in both air temperature and length of the growing season (Saunders \& Byrne 1994, Herrington et al. 1997). These factors, along with the precipitation results shown here, need further analysis to gain a better understanding of variations in Prairie growing season climate (including droughts) both in the past and the future.

A substantial portion of variance in monthly Prairie precipitation is explained by the defined synoptic scale atmospheric indices at the mid-tropospheric and, to a lesser degree, surface levels. At the $500 \mathrm{hPa}$ level, these indices are likely representative of larger, hemispheric teleconnection patterns over the Northern Hemisphere. In particular, the derived MI is significantly correlated with the typical PNA index (Wallace $\&$ Gutzler 1981) during every growing season month. The PNA is also significantly related to monthly growing season precipitation on the Prairies (see Knox \& Lawford 1990). However, the MI and $\mathrm{ZI}$ indices from this investigation explain a higher proportion of variance. As a result, they are a better estimator of precipitation variability on the Prairies (while still identifying variations in larger scale flow over North America).
It is recognized that atmospheric analysis is based on average monthly circulation and smaller time scales would likely provide a more comprehensive understanding of precipitation variability. Nonetheless, monthly values display preferred circulation modes and are indicative of the synoptic scale atmospheric controls governing precipitation on the Prairies. The results shown here may help in the prediction of Prairie growing season precipitation based on monthly forecasts at the $500 \mathrm{hPa}$ level over North America. Additionally, future changes in precipitation amounts and temporal distribution could be inferred from larger scale mid-tropospheric patterns simulated by GCMs (General Circulation Models).

Time series of the atmospheric indices generally display substantial interannual variability, with only a few significant decadal scale changes evident. These include May $500 \mathrm{hPa}$ and SLP MI, and J uly and A ugust $\mathrm{ZI}_{\mathrm{SLP}}$. In 1974, both May MI indices showed a significant decrease, while precipitation significantly increased (Fig. 10). This suggests that, since the mid 1970s, there has been a tendency for less mid-tropospheric ridging (troughing) over western (eastern) North America during May (see Fig. 8). Substantial changes in J uly and August $\mathrm{ZI}_{\mathrm{SLP}}$ have been alluded to previously in Figs. $13 \& 14$. The analysis reveals that interdecadal variability in the continental low over the United States, the high pressure over the Arctic, and the eastern Canadian low have influenced later growing season precipitation on the Prairies. The most notable of these variations involved a substantial decrease in surface pressures over the continental United States from approximately the mid 1970s to the present (Fig. 14a). Reasons for the observed decadal scale variability in mid-tropospheric and surface circulation patterns are not known and require further investigation. Possible explanations may involve interdecadal atmosphere-ocean variations in the Pacific (e.g. Trenberth \& Hurrell 1994, Mantua et al . 1997), the Atlantic (e.g. Hurrell 1995), or perhaps, in the case of the continental low over the United States, a response to the build-up of greenhouse gases in the atmosphere.

In conclusion, this study examines the amount and temporal distribution of precipitation within the growing season on the Canadian Prairies and the associated atmospheric circulation patterns. It demonstrates the importance in the temporal distribution of precipitation; a factor that should be considered in the analyses of past and future climatic variability. It is realized that the investigation focuses on larger spatial and temporal scales and that further analysis both regionally within the Prairies and temporally within the growing season may provide more insight. This study can be considered an initial step in identifying and understanding the causes of growing season precipitation 
variability on the Canadian Prairies. The results could also aid in the prediction of future growing season climates which would provide many economic benefits to the Prairie region.

Acknowledgements. The authors are grateful to $\mathrm{Dr} J$ ohn Knox and A mir Shabbar of the A tmospheric Environment Service for their helpful comments and Eva Mekis for the provision of the adjusted daily precipitation data for our study. We also thank the 3 anonymous reviewers for their useful suggestions toward an improved version of the manuscript.

\section{LITERATURE CITED}

Bethea RM, Duran BS, Boullion TL (1995) Statistical methods for engineers and scientists. Marcel Dekker Inc, New York, p 165-178

Bootsma A (1994) Long term (100 Yr) climatic trends for agriculture at selected locations in Canada. Clim Change 26: 65-88

Borchert J R (1950) The climate of the central N orth American grassland. Ann Assoc Am Geogr 40:1-39

Canadian National Committee for the International Decade for Natural Disaster Reduction (1994) Canadian National Report. Prepared for the IDNDR Mid-Term Review and the 1994 World Conference on Natural Disaster Reduction, Yokohama, J apan, 23-27 M ay 1994. Royal Society of Canada, Canadian Academy of Engineering, Ottawa, ON

Chakravarti AK (1972) The J une-J uly precipitation patterns in the Prairie Provinces of Canada. J Geogr 71:155-160

Dey B (1977) Nature and possible causes of heavy summer precipitation in the Canadian Prairies. Geogr Perspect 40: 26-33

Dey B (1982) Nature and possible causes of droughts on the Canadian Prairies-case studies. J Climatol 2:233-249

Dey B, Chakravarti AK (1976) A synoptic climatological analysis of summer dry spells in the Canadian Prairies. Gt Plains Rocky M tn Geogr J 5:30-46

Groisman PY, Easterling DR (1994) Variability and trends of total precipitation and snowfall over the United States and Canada. J Clim 7:184-205

Harman J R (1991) Synoptic climatology of the westerlies: process and patterns. Association of American Geographers, Washington, DC

Harman J R, Braud DH (1975) Flow patterns at the $500 \mathrm{mb}$ level and the prairie-forest ecotone in Canada. Mich Acad 7:347-356

Harrington J A J r, Cerveny RS (1989) Temporal statistics: an application in snowfall climatology. Phys Geogr 9:337-353

Herrington R, J ohnson B, Hunter F (1997) Responding to global climate change in the Prairies. Canada country

Editorial responsibility: Brent Yarnal,

University Park, Pennsylvania, USA study: climate impacts and adaptation, Vol III. Adaption and Impacts Section, Atmospheric Environment Branch, Environment Canada, Edmonton, AB, p 16-17

Hurrell J W (1995) Decadal trends in the North Atlantic Oscillation: regional temperatures and precipitation. Science 269:676-679

J ones PD (1987) The early twentieth century Arctic Highfact or fiction? Clim Dyn 1:63-75

Karl TR, Riesbame WE (1984) The identification of 10 to 20year temperature and precipitation fluctuations in the contiguous United States. J Clim Appl Meteorol 23:950-966

Karl TR, Knight RW, Easterling DR, Quayle RG (1995) Indices of climate change for the United States. Bull Am M eteorol Soc 77:279-292

Keables MJ (1989) A synoptic climatology of the bimodal precipitation distribution in the upper Midwest. J Clim 2: 1289-1294

Knox J L, Lawford RG (1990) The relationship between Canadian Prairie dry and wet months and circulation anomalies in the mid-troposphere. Atmos Ocean 28:189-215

Longley RW (1972) The climate of the prairie provinces. Climatological Studies \#13, Atmospheric Environment Service, Department of the Environment, Ottawa

M antua NJ , Hare SR, Zhang Y, Wallace J M, Francis RC (1997) A Pacific interdecadal climate oscillation with impacts on salmon production. Bull Am M eteorol Soc 78:1069-1079

Maybank J , Bonsal B, J ones K, Lawford R, O'Brien EG, Ripley EA, Wheaton E (1995) Drought as a natural disaster. Atmos Ocean 33:195-222

Mekis E, Hogg WD (1999) Rehabilitation and analysis of Canadian daily precipitation time series. Atmos Ocean (in press)

Norman GR, Streiner DL (1986) PDQ statistics. BC Decker Inc, Toronto, ON

Sabbagh ME, Bryson RA (1962) Aspects of the precipitation climatology of Canada investigated by the method of harmonic analysis. Ann Assoc Am Geogr 52:426-440

Saunders IR, Byrne J M (1994) Annual and seasonal climate and climatic changes in the Canadian Prairies simulated by the CCC GCM. Atmos Ocean 32:621-641

Shabbar A, Higuchi K, Knox JL (1990) Regional analysis of Northern Hemisphere $50 \mathrm{kPa}$ geopotential heights from 1946 to 1985. J Clim 3:543-557

Skeeter BR (1990) Variations in the association between midtropospheric flow and surface temperatures across the United States. Ann Assoc Am Geogr 80:590-602

Trenberth KE, Hurrell J W (1994) Decadal atmosphere-ocean variations in the Pacific. Clim Dyn 9:303-319

Wallace J M, Gutzler DS (1981) Teleconnection in the geopotential height field during the Northern Hemisphere winter. M on Weather Rev 108:615-630

Wheaton EE, Arthur LM, Chorney B, Shewchuck S, Thorpe J, Whiting J, Wittrock J (1992) The Prairie drought of 1988. Clim Bull 26:188-205

Submitted: September 17, 1998; Accepted: December 12, 1998 Proofs received from author(s): M arch 3, 1999 